\title{
Single Incision Laparoscopic Bariatric Surgery: Challenging the Conventional
}

\author{
REYNU R, NEERAJ K, KOSAI NR
}

Minimally Invasive, Upper Gastrointestinal and Bariatric Surgery Unit, Department of Surgery, Faculty of Medicine, Universiti Kebangsaan Malaysia Medical Centre, Jalan

Yaacob Latif, Bandar Tun Razak, 56000 Cheras, Kuala Lumpur, Malaysia.

\begin{abstract}
ABSTRAK
Pembedahan 'sleeve gastrectomy' semakin popular kebelakangan ini dan kebiasaannya dijalankan menggunakan kaedah laparoskopi yang memerlukan beberapa potongan kecil di atas kulit. Kehadiran pembedahan laparoskopik insisi tunggal telah membolehkan pembedahan 'sleeve gastrectomy' kini dilakukan menerusi satu luka kecil yang lebih kosmetik justeru meningkatkan kepuasan pesakit. Menerusi artikel ini, kami cuba untuk menerangkan sejarah, kekangan teknikal, cadangan untuk mengatasi cabaran-cabaran yang mungkin timbul dalam pembedahan bariatrik laparoskopik insisi tunggal dan teknik pilihan kami sewaktu menjalankan pembedahan laparoskopik insisi tunggal 'sleeve gastrectomy' secara eksklusif melalui hanya satu alat akses ke rongga peritoneal.
\end{abstract}

Kata kunci: laparoskopi, bariatrik, obesiti, kosmetik, sleeve gastrectomy

\begin{abstract}
Sleeve gastrectomy has gained popularity over the years and is commonly performed laparoscopically through multiple small incisions. The arrival of single incision laparoscopic surgery has been a game changer, allowing for sleeve gastrectomy to be performed through a cosmetically more appeasing scar with improved patient satisfaction. In this article, we describe the history, technical challenges, proposed solutions to some of the hurdles faced during single-incision laparoscopic bariatric surgery and highlight our method of performing single incision laparoscopic sleeve gastrectomy purely through a single access device.
\end{abstract}

Keywords: bariatric, cosmetic, laparoscopy, obesity, sleeve gastrectomy

Single incision laparoscopic surgery has become increasingly popular among surgeons and the medicaldevice industry, with some even calling

Address for correspondence and reprint requests: Reynu Rajan, Minimally Invasive, Upper Gastrointestinal and Bariatric Surgery Unit, Department of Surgery, Faculty of Medicine, Universiti Kebangsaan Malaysia Medical Centre, Jalan Yaacob Latif, Bandar Tun Razak, 56000 Cheras, Kuala Lumpur, Malaysia. Tel: +603 91456201 Fax: +603-91456684 E-mail: dr.reynu@gmail.com 
it the Holy Grail of Minimal Access Surgery with its near-scarless effect. The cosmetic advantage, familiarity of laparoscopic view observed with this technique and the freedom to convert single incision laparoscopic surgery to a conventional laparoscopic surgery has made this approach irresistible to modern day surgeons despite being technically demanding. Single incision laparoscopic surgery has been referred to by many names such as Single Port Access (SPA), Embryonic Natural Orifice Transumbilical Endoscopic Surgery (E-NOTES), Single Incision Multi Port Laparo-Endoscopic Surgery (SIMPLE) and Single Port Surgery (SPS) just to name a few. This is largely due to the absence of consensus among surgeons to adopt a standardized nomenclature. In 2008, a multidisciplinary consortium of surgeons also known as the LaparoEndoscopic Single Site Surgery Consortium for Assessment and Research (LESSCAR) attempted to put an end to this confusion and suggested the name Laparo-Endoscopic Single Site Surgery or "LESS Surgery" to be applied when describing a procedure through a single site of access - a decision that has yet to garner undivided support from the global bariatric surgery community at large.

\section{EVOLUTION OF SINGLE INCISION LAPAROSCOPIC BARIATRIC SURGERY}

Despite the new found fan-fare, single incision laparoscopic surgery is no "New Kid on the Block". Gynecologists have been performing single incision laparoscopic tubal ligation since the 70s (Bailer \& Rauskolb 1975). In 1992, the first single incision laparoscopic supracervical hysterectomy was reported in the Journal of Reproductive Medicine (Pelosi \& Pelosi 1992). This approach further expanded in general surgery to perform single incision laparoscopic cholecystectomy (Navarra et al. 1997). Later, the use of single incision laparoscopic appendectomy was performed successfully in children (Esposito et al. 2007). But it was not until 2008 that the surgical fraternity would read about a single incision laparoscopic bariatric surgery (SILBS), the year that the first single incision laparoscopic adjustable gastric banding was reported (Nguyen et al. 2008). The same year, report of the first single incision laparoscopic sleeve gastrectomy was published (Saber et al. 2008). A year later in 2009, Saber and team reported the first single port access laparoscopic Roux-en-Y gastric bypass surgery and since then has gone on to publish numerous scientific papers on the feasibility and safety of single incision laparoscopic bariatric procedures in varying class of obesity (Saber et al. 2009). The first wave of this near-scarless bariatric surgery revolution arrived on the shores of Asia circa 2009-2011 (Huang et al. 2009; Lakdawala et al. 2011).

\section{SITE OF INCISION}

SILBS can be performed through a horizontal incision in the upper abdomen (single incision transabdominal or SITA) in patients with a xiphoid-umbilicus distance of more than $25 \mathrm{~cm}$. In patients with 
xiphoid-umbilicus distance of $25 \mathrm{~cm}$ or less, SILBS can be performed through a hidden transumbilical incision (single incision transumbilical or SITU). SITU has been associated with increased patient satisfaction, improved cosmesis and less pain compared to its transabdominal counterpart. Circumumbilical incision and Omega incision have also been reported and can be applied as an alternative to the incision used in the SITU approach. Once the incision has been made, laparoscopic instruments are introduced into the abdominal cavity either through a single access device such as SILSTM Port (Medtronic) and GelPort ${ }^{\circledR}$ (Applied Medical) or alternatively by introducing 3-4 laparoscopic trocars directly through the abdominal wall via different facial planes i.e. single incision-multiport laparoendoscopic technique (SIMPLE).

\section{LIVER RETRACTION}

Good liver retraction facilitates creation of adequate working space for laparoscopic upper gastrointestinal procedures to be performed. By lifting the hypertrophied left liver lobe, the surgeon is able to better visualize the Angle of His, thus reducing the risk of possible injury to this area during dissection or gastric stapling. The additional space also enables the surgeon to perform complete mobilization of the posterior fundus during surgery. Various liver retractions techniques have been reported over the years from application of a regular Nathanson liver retractor to the more cosmetically appeasing methods described by various surgeons (Sakaguchi et al. 2008), (Huang 2011) and (Tacchino et al. 2010).

\section{TECHNICAL CHALLENGES WITH SILBS}

SILBS did have its own teething problems in the beginning which were quickly overcome by a timely influx of advanced laparoendoscopic gadgetry and innovative modification to existing technology. Among the challenges of performing SILBS were the loss of triangulation, "sword-fighting" between laparoscopic instruments, friction between the internal and external components of laparoscopic trocars, the risk of port site hernia, difficulty in maintaining pneumoperitoneum due to leakage of gas, inadequate exposure of vital structures, clash between the bulky camera head and the surgeon's hand and risk of direct damage to the telescope itself. Existing anatomical features in obese individuals such as hepatomegaly or hypertrophied left lobe of liver, visceral adiposity and torque of the thick abdominal wall adds to the list of potential challenges. If not for technical improvisation by an innovative breed of surgeons, and the race to produce single incision friendly laparoscopic devices by corporate giants in the med-tech field, it would have not been possible for SILBS to grow and evolve at its current rate (Table 1).

\section{BARIATRIC SURGERY IN MALAYSIA}

Malaysia's footprint in bariatric surgery began in 1996 with the first open 
Table 1: Suggested solutions to some of the challenges faced by surgeons during single incision laparoscopic bariatric surgery

\begin{tabular}{|c|c|}
\hline $\begin{array}{l}\text { Challenges Faced by Single Incision } \\
\text { Laparoscopic Surgeons }\end{array}$ & Solutions \\
\hline \multirow[t]{2}{*}{ Loss of triangulation } & $\begin{array}{l}\text { Articulating instruments such as SILS }{ }^{T M} \text { Articulating Hand } \\
\text { Instruments (Medtronic) }\end{array}$ \\
\hline & $\begin{array}{l}\text { Pre-bent laparoscopic instruments such as S-Portal Series } \\
\text { (Karl Storz)\&HiQ LS Pre-bend hand instruments (Olympus) }\end{array}$ \\
\hline $\begin{array}{l}\text { Clashing of trocars (within the abdominal } \\
\text { cavity and externally outside the abdominal } \\
\text { wall) }\end{array}$ & Short or low profile trocars (Applied Medical) \\
\hline $\begin{array}{l}\text { Clashing of camera head or light source of } \\
\text { laparoscope with surgeon's hands }\end{array}$ & $\begin{array}{l}\text { Extended length telescopes }(55 \mathrm{~cm}) \text { or laparoscope with } \\
\text { a more streamlined light source on camera head such as } \\
\text { HOPKINS telescopes (Karl Storz) }\end{array}$ \\
\hline $\begin{array}{l}\text { Clashing of instruments with laparoscope } \\
\text { within the abdominal cavity }\end{array}$ & Deflectable tip laparoscope such as EndoEyeby Olympus \\
\hline \multirow[t]{2}{*}{ Lack of hiatal exposure } & $\begin{array}{l}30 \text { degree or } 45 \text { degree telescopes for better visualization } \\
\text { of difficult angles such as HOPKINS telescopes(Karl Storz) }\end{array}$ \\
\hline & $\begin{array}{l}\text { Atraumatic liver retractors (Snowden Pencer Diamond Flex } \\
\text { Articulating Triangular Liver Retractor), right crux transfixion } \\
\text { sutures or liver suspension tapes to elevate the liver. }\end{array}$ \\
\hline Tissue sealing and hemostasis & $\begin{array}{l}\text { New and improved energy devices such as } \text { LigaSure }^{\top M} \\
\text { Maryland jaw (Medtronic), ENSEAL } ® \text { G2 Articulating Tissue } \\
\text { Sealer (Ethicon) or THUNDERBEAT in-line grip (Olympus) }\end{array}$ \\
\hline
\end{tabular}

vertical gastroplasty. Since then there has been 2009 bariatric procedures performed up till December 2016. Interestingly, approximately 1787 of those cases were performed over a short span of 7 years from 2010 to 2016. In 2016 alone, 463 cases carried out throughout the country, a steep jump from merely 158 cases in 2010. The positive growth of bariatric surgery in Malaysia over the years is a testament to the courage, drive and commitment shown by local pioneers in the field. Their passion for improving patient outcome and increasing training opportunities for surgeons have paved the way for a whole new generation of surgeons to step in and be a part of this exiting time in bariatric surgery - one that has seen the Malaysian bariatric scene transitioning from open surgery to laparoscopic surgery to reduced incision laparoscopic surgery and now single incision laparoscopic surgery.

\section{FIRST SILBS IN MALAYSIA}

Our first experience with single incision laparoscopic sleeve gastrectomy at UKMMC and Malaysia, dates back to the year 2016. The surgery was carried out through the SITU approach using SILSTM Port (Medtronic) and straight laparoscopic instruments. The left lobe of liver was elevated using the right crux transfixion technique with a single 


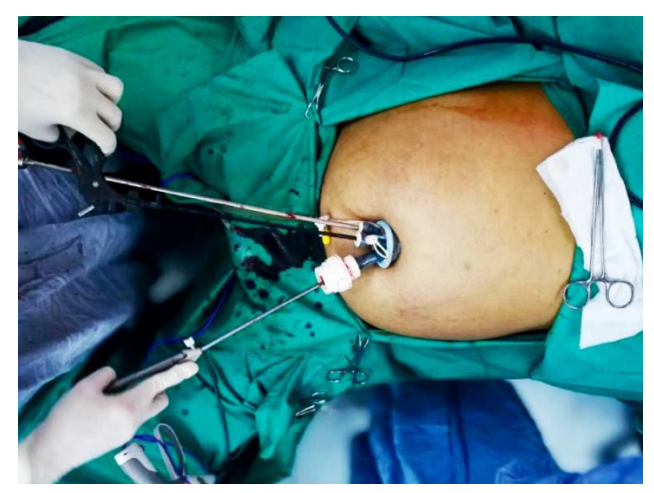

Figure 1: Photograph depicting the single incision laparoscopic access device and straight instruments used during the SIL Sleeve Gastrectomy

Vicryl 2-0 suture. We then went on to successfully complete Malaysia's first pure single incision laparoscopic sleeve gastrectomy in 2017. The surgery was carried out in a similar fashion as before but with one exception - there was no additional incision at the epigastrium for an ancillary trocar, needlescopic instruments or puppeteering sutures to retract the liver (Figure 1). The only incision on the body was a single hidden transumbilical incision measuring $3 \mathrm{~cm}$ in length (Figure 2). Intra-operative visualisation of the Angle of His was achieved by neatly packing 4 pieces of gauze beneath the left lobe of liver in order to elevate it (Figure 3). The stomach was separated from the omentum along the greater curvature using LigaSure ${ }^{\mathrm{TM}}$ Maryland jaw $44 \mathrm{~cm}$ long (Medtronic). The gastric tube was created using iDrive ${ }^{\mathrm{TM}}$ Ultra Powered Stapling Device with $60 \mathrm{~mm}$ Tri-Staple ${ }^{T M}$ cartridge (Medtronic). The stapler line was then reinforced with V-Loc ${ }^{\mathrm{TM}}$ wound closure device (Medtronic) along its entire length. The resected specimen was then delivered

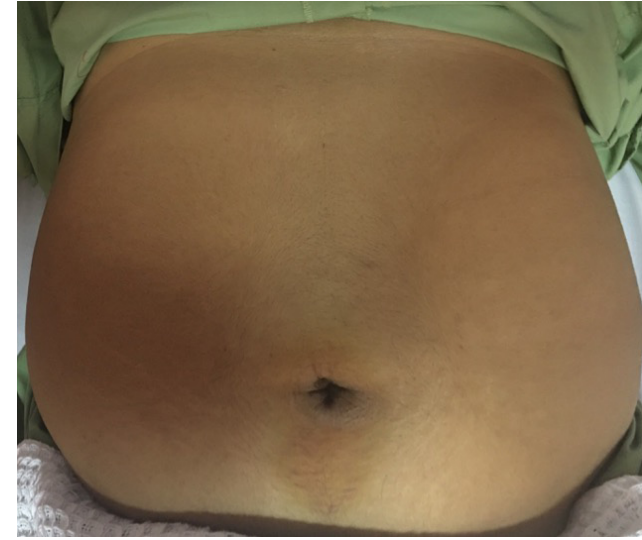

Figure 2: Photograph depicting a single hidden transumbilical incision scar (immediate postoperative) following a pure single incision laparoscopic sleeve gastrectomy

through the transumbilical incision (Figure 4). Patient was allowed clear fluids the next day and discharged on post-operative day 2. This method resulted in greater patient satisfaction, improved cosmesis and less pain compared to the conventional method of performing laparoscopic sleeve gastrectomy which involves making 5 separate incisions over the anterior abdominal wall (Figure 5). From extensive literature review, we do believe that this is the first descriptive account of Malaysia's involvement, history and progress in the field of Bariatric surgery as well as the first report of a successful pure single incision laparoscopic sleeve gastrectomy in Malaysia.

\section{FUTURE DIRECTION OF SILBS IN MALAYSIA}

Despite the positive trend of volume of bariatric cases in Malaysia, acceptance of SILBS among local surgeons has been somewhat lukewarm. In the era of cost-effectiveness, the large amount 


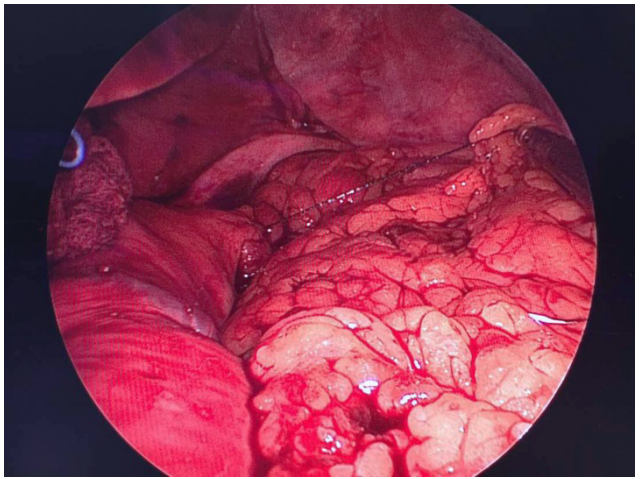

Figure 3: Intra-operative photograph taken during the single incision laparoscopic sleeve gastrectomy. The gauze beneath the liver is visible (for liver retraction) and the surgeon has just begun to take the first stitch above the stapler line with intention to imbricate the entire stapler line of the gastric tube (V-Loc suture)

of investment needed to purchase single incision specific laparoscopic equipment, the added cost in the form of procedural fee that a patient would have to endure for purchase of the SILBS access device and the lack of training opportunities in SILBS are among plausible factors that have restricted the popularity of SILBS. However, with record number of industry players showing interest in the this "scarless revolution", operational cost for the surgeon or institution and procedural cost for the patient is expected to reduce, increasing the reach and feasibility of SILBS in Malaysia.

\section{REFERENCE}

Bailer, P., Rauskolb, R. 1975. Gynaecological laparoscopy. Geburtshilfe Frauenheilkd 35(10): 747-53.

Esposito, C., Borzi, P., Valla, J.S., Mekki, M., Nouri, A., Becmeur, F., Allal, H., Settimi, A., Shier, F., Sabin, M.G., Mastroianni, L. 2007. Laparoscopic versus open appendectomy in children; a retrospective comparative study of 2332 case. World J Surg 31(4): 750-5.

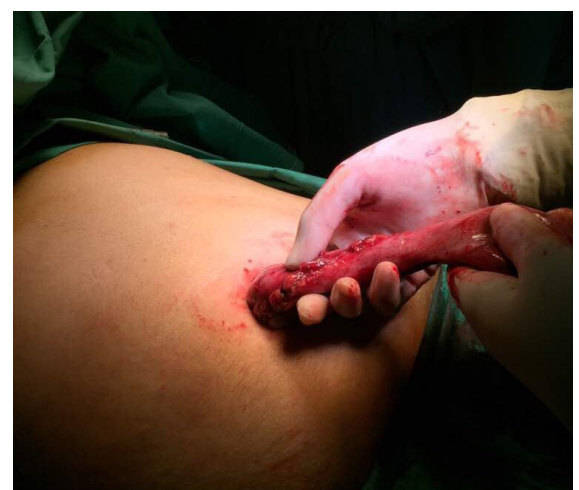

Figure 4: Photograph depicting the removal of resected gastric specimen through the transumbilical incision

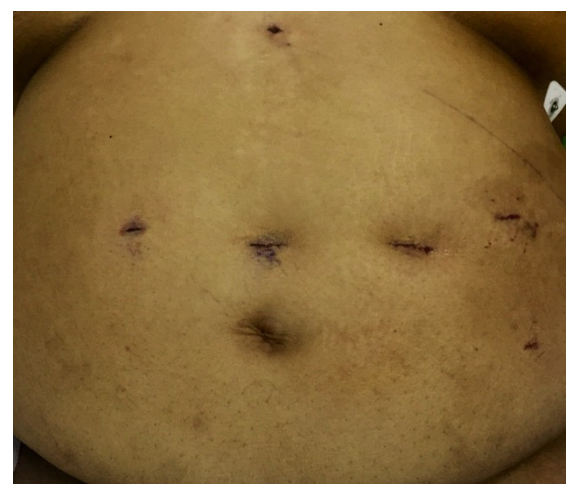

Figure 5: Photograph depicting the immediate post-operative scars following a conventional 5-port (or 5-incision) laparoscopic sleeve gastrectomy

Huang, C.K., Houng, J.Y., Chiang, C.J., Chen, Y.S., Lee, P.H. 2009. Single incision transumbilical laparoscopic Roux-en-Y gastric bypass: a first case report. Obes Surg 19(12): 1711-5.

Huang, C.K. 2011. Single-incision laparoscopic bariatric surgery. J Minim Access Surg 7(1): 99-103.

Lakdawala, M.A., Muda, N.H., Goel, S., Bhasker, A. 2011. Single-incision sleeve gastrectomy versus conventional laparoscopic sleeve gastrectomy--a randomised pilot study. Obes Surg 21(11): 1664-70.

Navarra, G., Pozza, E., Occhionorelli, S., Carcoforo, P., Donini, I. 1997. One-wound laparoscopic cholecystectomy. Br J Surg 84(5): 695.

Nguyen, N.T., Hinojosa, M.W., Smith, B.R., Reavis, K.M. 2008. Single laparoscopic incision transabdominal (SLIT) surgery-adjustable gastric banding: A novel minimally invasive surgical approach. Obes Surg 18(12): 1628-31. 
Pelosi, M.A., Pelosi, M.A. 1992. Laparoscopic supracervical hysterectomy using a singleumbilical puncture (minilaparoscopy). J Reprod Med 37(9): 777-84.

Saber, A.A., Elgamal, M.H., Itawi, E.A., Rao, A.J. 2008. Single incision laparoscopic sleeve gastrectomy (SILS): a novel technique. Obes Surg 18(10): 1338-42.

Saber, A.A., El-Ghazaly, T.H., Minnick, D.B. 2009. Single port access transumbilical laparoscopic Roux-en-Y gastric bypass using the SILS Port: first reported case. Surg Innov 16(4): 343-7.
Sakaguchi, Y., Ikeda, O., Toh, Y., Aoki, Y., Harimoto, N., Taomoto, J., Masuda, T., Ohga, T., Adachi, E., Okamura, T. 2008. New technique for the retraction of the liver in laparoscopic gastrectomy. Surg Endosc 22(11): 2532-4.

Tacchino, R.M., Greco, F., Matera, D. 2010. Laparoscopic gastric banding without visible scar: A short series with infraumbilical SILS. Obes Surg 20(2): 236-9.

Received: 6 April 2017

Accepted: 30 May 2017 